\title{
ANALISIS PRAKTIK AKAD MUZARA'AH DI DESA LEBAK KECAMATAN SANGKAPURA BAWEAN GRESIK PERSPEKTIF HUKUM ISLAM
}

\author{
Ainun Barakah, Pipin Suitra \\ STAI Hasan Jufri Bawean \\ anbariyah_sahla@yahoo.com/ganna_firdaus@yahoo.com
}

\begin{abstract}
Bawean is an archipelago administratively included in Gresik Regency, where the main occupation of the people is farming and fishing, but not all of the people have land to farm and ships to go to sea, and not a few who work in Malaysia and Singapore have even become citizens of that country. so that the land and rice fields below are unproductive, so there is cooperation between landowners and tenants or cultivators, in agricultural practices, landowners and processors or workers often make contracts and agreements in such cooperation, as well as in the village of Lebak, the agreement sees to the weather, or irrigation used to irrigate rice fields, and the yields obtained during the rainy season in certain months are different, there are at least three cooperation systems in the muzara'ah contract implemented there, in this study the three systems were analyzed to determine which in accordance with Islamic law , of the three, there are two agreements that use the muzara'ah contract, and the other one uses the ijarah agreement or lease agreement. This research uses the library research method with a qualitative inductive approach.
\end{abstract}

Keywords: muzara'ah, Islamic Law, Gresik

\section{Pendahuluan}

Bawean adalah sebuah pulau kecil yang berlokasi di perairan laut jawa dengan jarak sekitar $120 \mathrm{~km}$ dari kabupaten gresik, pulau ini terdiri dari dua kecamatan yaitu kecamatan Sangkapura dan Tambak. Bawean adalah pulau agraris yang sumber penghidupan mayoritas masyarakatnya adalah bercocok tanam. Mereka memberdayakan persawahan untuk penanaman padi dengan curah hujan, sehingga penanaman padi serentak akan dilakukan pada musim penghujan (kategeh), dan tidak banyak yang mengandalkan air sungai untuk irigasi. 
Lebak adalah salah satu desa di kecamatan Sangkapura yang memiliki tujuh dusun, hampir semua penduduknya menanam padi, karena lokasi desanya dari laut agak jauh sekitar dua hingga tiga kilometer, dan areanya yang datar dan luas lebih prospek dijadikan lahan persawahan dan pertanian.

Akad muzara'ah lazim dilakukan di desa Lebak ini, hal itu disebabkan beberapa hal yaitu jenjang perekonomian masyarakatnya yang bertingkat, dan tidak sedikit penduduknya yang berada di luar negeri seperti Malaysia, Singapura dan Australia, sehingga pemilik tanah dari kalangan berada yang tidak sanggup mengelolah sawah-sawahnya begitu juga yang menetap di luar negeri bahkan menjadi penduduk di sana menyerahkan sawah-sawahnya untuk digarap oleh penduduk setempat yang tidak memiliki lahan atau memerlukan perluasan garapan, dengan akad muzara'ah.

Spirit dari praktik muzara'ah ini sesuai dengan nilai-nilai keislaman yang sangat menganjurkan kerjasama, saling tolong menolong dalam kebaikan, dan pada kenyataannya sangat dibutuhkan di masyarakat, oleh karena itu mayoritas fukaha membolehkan akad muzara'ah sebagaimana firman Allah Ta'ala :

$$
\text { ....وتعاونوا على البر و التقوى و لا تعاونو ا على الإثم و العدوان، و اتقوا الله إن الله شديد العقاب (المائدة : 2) }
$$

.....dan tolong menolonglah kamu dalam mengerjakan kebajikan dan takwa, dan jangan tolong menolong dalam berbuat dosa dan permusuhan. Bertakwalah kepada Allah, sungguh Allah sangat berat siksanya

Jika merujuk kepada kamus al mu'jam al wasith, lisan al'Arab serta al Mishbah al Munir, Muzara'ah adalah kerjasama dalam mengelolah tanah dengan sebagian apa yang dihasilkan tanah tersebut. Adapun makna muzara'ah secarah terminology Syariah didefinisikan oleh fuqaha sebagai berikut :

Menurut hanafiyah : muzara'ah adalah akad dalam pengelolaan sawah dengan sebagian hasil sawah. Menurut Malikiyah adalah kerjasama dalam pengelolaan sawah. Menurut Syafi'iyah adalah akad atas pengelolaan sawah dengan sebagian hasil yang diperoleh dari sawah tersebut dan bibit dari pemilik 
tanah, sedangkan menurut Hanabilah adalah menyerahkan sawah beserta bibitnya kepada orang yang mengelolah. ${ }^{1}$

\section{a. Hukum Muzara'ah}

Ada perbedaan pendapat para fuqaha tentang kebolehan akad muzara'ah, akan tetapi jumhur ulama memperbolehkannya memandang betapa akad ini sangat dibutuhkan oleh masyarakat baik itu pemilik tanah atau pengelolah, karena banyak dari pemilik tanah yang tidak mampu menggarap sendiri tanahnya begitupun penggarap yang tidak memiliki tanah, sehingga diperbolehkan akad ini kendati upah yang diberikan pemilik tanah berupa sebagian hasil dari panen.

Dalam hal ini ulama syafi'iyah melarang praktik muzara'ah (bibit dari pemilik lahan) dan mukhabarah (bibit dari penggarap) karena dianggap ada gharar di dalamnya dengan merujuk kepada hadits-hadits yang melarang praktik tersebut, namun sebagian lagi membolehkan.

Penggarapan tanah dapat dilakukan dengan dua cara: pemilik tanah itu sendiri yang mengerjakannya atau dia serahkan penggarapan itu kepada orang lain dengan bagi hasil atau sewa. Jika tanah diberikan oleh pemiliknya kepada orang lain untuk digarap, itu disebut persewaan (tenancy) atau muzara'ah. Ada dua jenis tenancy, yakni yang pertama adalah pemilik dan penggarap membagi hasil produksi dan ini disebut share-tenancy, yang kedua penggarap membayar uang sewa kepada pemilik tanah, dan ini disebut cash-tenancy. ${ }^{2}$

Dalam akad muzara'ah share tenancy, ada empat beberapa gambaran, tiga diantaranya diperbolehkan dan satu yang lain tidak diperkenankan ${ }^{3}$ yaitu :

1. Tanah dan bibit dari satu pihak, sedangkan penggarapan berikut peralatan dan lainnya dari pihak yang lain, kesepakatan ini diperbolehkan

\footnotetext{
${ }^{1}$ Wizarat al Auqaf wa as Syuun al Islamiyah, Al mausu'ah al fiqhiyah, (Kuwait, Dar as Shofwah, Kuwait, 1997) juz 37, 49

2 Muhammad Syarif Caudhry, Sistem Ekonomi Islam Prinsip Dasar (Jakarta, Prenadamedia Group, 2012), 168.

${ }^{3}$ Wahbah az Zuhaili, al Fiqhu al Islam wa Adillatuhu, (Damaskus, Dar al Fikr, 1985), juz 5, 621
} 
2. Tanah dari satu pihak, sedangkan bibit dan lainnya dari pihak yang lain yaitu penggarap, akad ini juga diperbolehkan.

3. Tanah, bibit dan peralatan dari satu pihak, sedangkan penggarapan dari pihak lain, akad model ini juga diperbolehkan.

4. Tanah dan peralatan dari satu pihak yaitu pemilik lahan, sedangkan bibit dan penggarapan dari pihak lain, jenis ke empat ini dilarang, dengan alasan bahwa jika akadnya dianggap perjanjian ijarah untuk pemilik lahan yang dalam hal ini berstatus sebagai pemilik sewa lalu penyewa mensyaratkan peralatan kepada pemilik lahan maka hal itu merusak akad karena peralatan itu sesuatu yang terpisah dari lahan yang artinya keduanya mempunyai manfaat yang berbeda, begitu juga jika perjanjian dianggap sebagai ijarah dengan status penggarap sebagai pemberi sewa atas tenaga dan usahanya maka mensyaratkan bibit terhadapnya merusak akad.

b. Rukun Muzara'ah

Menurut jumhur Ulama rukun muzara'ah ada tiga yaitu dua orang yang bertransaksi dalam hal ini pemilik tanah dan pengelolah, tanah dan bibit, dan shigah yaitu ijab dan qabul.

c. Selesainya Akad Muzara'ah

Akad muzara'ah dianggap selesai jika tujuannya sudah tercapai yaitu panen, namun dalam beberapa keadaan akad tersebut selesai walaupun tujuannya belum tercapai, yaitu :

1. Selesainya masa tanam menanam

Akad dengan sendirinya selesai jika maksud dan tujuannya tercapai, namun jika waktu yang disepakati telah habis, dan tanaman belum panen maka akadnya berlanjut hingga panen dan hasil dibagi dua sesuai kesepakatan, hal itu demi menjaga maslahat kedua belah pihak. ${ }^{4}$ Pada kondisi ini pembiayaan untuk tanaman baik itu pemeliharaan, irigasi, adalah tanggung jawab kedua belah pihak sesuai bagiannya masing-masing yang telah disepakati.

\footnotetext{
${ }^{4}$ Wahbah az Zuhaili, Fiqhu al Islam wa Adillatuh, (Damaskus, Dar alFikr 1985) juz 5, cet.2, 626
} 
2. Wafatnya salah satu yang berakad

Menurut jumhur fukaha, akad muzara'ah tidak selesai begitu saja dengan wafatnya salah satu yang berakad seperti halnya yang berlaku pada akad ijarah yang apabila salah satu yang berakad meninggal dunia maka secara otomatis akadnya terhenti, namun ada juga pendapat yang mengatakan bahwa akadnya terhenti otomatis.

Jika pemilik tanah meninggal dunia sedangkan tanaman belum panen maka kesepakatan berlanjut antara pengelolah dengan ahli waris dari pemilik tanah, dan jika yang meninggal adalah pengelolah maka ahli warisnya yang melanjutkan penggarapan, dan mereka tidak berhak diupah atas pekerjaan yang mereka lakukan, karena sejatinya mereka sedang melanjutkan kesepakatan sebelumnya.

3. Pembatalan akad

Akad dianggap terhenti dengan pembatalan dari salah satu pihak, dengan syarat pembatalan tersebut terjadi sebelum prosesnya belum dimulai, namun menurut mazdhab Hanafi pembatalan boleh dilakukan kendati prosesnya telah dimulai dan sedang berjalan, yaitu dalam kondisi mendesak, seperti lilitan hutang pemilik tanah, dan jatuh sakitnya si pengelolah tanah sehingga tidak bisa melanjutkan penggarapan, menurutnya juga akad muzara'ah itu adalah akad yang mengikat terhadap pihak yang tidak mengeluarkan bibit, maka pihak yang tidak memiliki bibit tidak boleh membatalkan sepihak.

d. Jaminan dalam akad Muzara'ah

Yang bertanggung jawab (yad amanah)terhadap tanaman adalah pengelolah (muzari'). Jika terjadi hal-hal yang tidak diinginkan seperti bencana berupa banjir, tanah longsor dan likuifaksi misalkan maka pengelolah tidak wajib bertanggung jawab, karena hal itu di luar kuasanya dan bukan kesengajaan darinya, sebaliknya jika kerusakan terjadi karena keteledoran dan kesengajaannya maka dia wajib bertanggung jawab atau ganti rugi dengan catatan akad yang terjadi antara pemilik dan penggarap adalah akad yang sah 
bukan akad yang fasid, jika akadnya fasid maka tidak ada kewajiban apapun atas pengelolah.

\section{e. Zakat Hasil Muzara'ah}

Bila pemilik itu menyerahkan penggarapan tanahnya itu kepada orang lain dengan imbalan seperempat, sepertiga atau setengah hasil sesuai perjanjian, maka zakat dikenakan atas kedua bagian pendapat masingmasing, bila cukup senishab dengan hasil tanaman lain, bila bagian salah satu sampai senishab sedangkan yang seorang lagi tidak, maka zakat wajib atas yang memiliki bagian yang cukup senishab sedangkan yang tidak cukup tidak wajib karena ia memiliki kekayaan yang tidak cukup senishab yang oleh karena itu tidak termasuk orang kaya, karena zakat hanya wajib atas orang kaya. ${ }^{5}$

Menurut pendapat di atas, maka zakat hasil panen ditentukan setelah hasilnya dibagi kepada pemilik tanah dan pengelolah, jika setelah pembagian mencapai nishab baik digabung dengan hasil panen yang lain atau tidak maka wajib mengeluarkan zakat bagi yang mencapainya adapun yang tidak mencapai nishab maka tidak wajib zakat.

Namun menurut madzhab Syafi'I kewajiban zakat berlaku atas keduanya baik itu pemilik lahan ataupun pengelolah. ${ }^{6}$ Pendapat ini menganggap bahwa nishab ditentukan sebelum hasil panen di bagi, jika mencapai nishab maka zakatnya dikelurkan kemudian sisanya dibagi sesuai bagian masing-masing yang telah disepakati dalam akad, atau dibagi terlebih dahulu kemudian zakatnya dikeluarkan masing-masing sesuai dengan kadar bagiannya.

f. Perbedaan antara muzara'ah dengan Musaqah

Pada dasarnya antara muzara'ah dan musaqah adalah sama-sama terkait dengan kerjasama dalam pertanian, dan sistemnya adalah bagi hasil dari tanaman yang digarap, namun bedanya pertama adalah, dalam muzara'ah

${ }^{5}$ Yusuf al Qardhawi, Fiqhu az Zakah, (Hukum Zakat,Terj. Salman Harun, (Jakarta, P.T. Pustaka Litera AntarNusa, 1991)375

${ }^{6}$ Ibid. 
antara pemilik tanah dan pengelolah sama-sama memiliki andil dan tanggung jawab dalam proses, seperti bibit atas pemilik dan alat dan biaya pengelolaan atas pengelolah, sedangkan dalam akad musaqah, yang bertanggung jawab terkait pembiayaan selama proses ada dalam tanggungan pengelolah. Perbedaan kedua adalah muzara'ah dimulai dari pembibitan hingga panen, sedangkan dalam musaqah tanaman atau pepohonan yang akan digarap sudah sedia, dan pengelolah hanya menjaganya, mengairinya hingga panen. Musaqah awalnya adalah sewa menyewa dan akhirnya adalah bagi hasil. Perbedaan ketiga, akad dalam muzara'ah tidak mengikat selama pekerjaan belum dimulai, sedangkan dalam musaqah akadnya mengikat, dalam hal ini ada khilaf di kalangan fukaha.

g. Kesepakatan-kesepakatan yang merusak akad

Ada beberapa kesepakatan yang bisa merusak kesah-an dari akad muzara'ah yaitu :

1. Kesepakatan bahwa hasil panen hanya dimiliki oleh salah satu pihak

2. Kesepakatan yang tidak jelas berapa bagian masing-masing pihak, atau menentukan bagiannya sesuai posisi tanah, semisal bagianku adalah hasil tanah bagian timur dan sebagainya.

3. Mensyaratkan pemilik tanah untuk ikut menjaga tanaman sebelum panen

4. Mensyaratkan pemilik tanah untuk ikut membantu dalam proses penggarapan.

5. Mensyaratkan pengelolah untuk melakukan sesuatu yang manfaatnya tetap ada walaupun setelah panen, seperti mensyaratkan pengelolah untuk membangun tembok di sekitar tanah, atau menggali parit yang besar.

6. Mensyaratkan bibit dari kedua belah pihak 


\section{Praktik Muzara'ah di Desa Lebak}

Setelah melakukan wawancara dengan dua orang penduduk Desa Lebak yang sekaligus pelaku dalam akad muzara'ah yaitu ibu Sholehah dan Ibu Tiyuk dari Dusun Lebak, dalam praktiknya setidaknya ada tiga beberapa sistem kerjasama yang digunakan di desa Lebak ini, yaitu :

1. Kesepakatan antara pemilik tanah dengan pengelolah bahwa bibit, pupuk dan zakat dari pemilik, system bagi hasilnya adalah pemilik memperoleh satu karung padi dari setiap satu kolak ${ }^{7}$ sawah, baik panennya sukses atau tidak, namun kesepakatan inipun bisa dirubah sewaktu-waktu sesuai kesepakatan kedua belah pihak.

2. Kesepakatan antara pemilik tanah dengan pengelolah bahwa pemilik tanah hanya memodali bibit,akan tetapi di samping itu kebiasaan yang berlaku pemilik tanah akan mengeluarkan pupuk atas nama bantuan kepada pengelolah, dan zakat dikeluarkan oleh pengelolah dan hasil panen dibagi dua dengan system fifty-fifty.

3. Kesepakatan antara pemilik tanah dengan pengelolah bahwa bibit, pupuk dan zakat dikeluarkan oleh pemilik tanah, system pembagian hasil tidak ditentukan dengan pasti di awal akad, pada kenyataannya pengelolah yang akan menentukan sepihak berapa bagian pemilik sawah.

\section{Analisis Akad}

Sebelum menganalisa ketiga akad di atas, harus ada pemetaan skema pembagian peran masing-masing pemilik dan pengelolah, supaya bisa diketahui apakah akadnya murni muzara'ah ataukah akad ijarah, jika muzara'ah apakah memenuhi syarat dan ketentuannya atau tidak, begitu juga dengan akad ijarah.

1. Pada gambaran akad pertama baik bibit, pupuk serta zakat dibebankan kepada pemilik tanah, adapun kesepakatan dalam hasil panen adalah

7 Sekitar 150 meter persegi 
bagian tertentu yaitu satu karung untuk satu kolak tanah bagi pemilik tanah, jika ditelaah maka disini akadnya adalah ijarah, karena pengelolah hanya menggarap, seolah pemilik tanah menyewa jasa pengelolah dalam menggarap tanahnya, namun ia juga muzara'ah karena penggarapan berikut peralatannya dari pihak pengelolah. Adapun yang perlu diperhatikan adalah bagian satu karung dari setiap satu kolak untuk pemilik tanah baik hasil panennya sukses atau tidak, artinya jika hasilnya sukses dan melimpah maka pemilik tanah hanya mendapatkan satu karung tersebut, dan sisanya dimiliki oleh pengelolah dan sebaliknya jika panennya gagal, maka pemilik tetap mendapatkan satu karung sementara pengelolah merugi.

Dari penggambaran tersebut dapat disimpulkan bahwa dalam akad tersebut ada gharar dan spekulasi karena ia tidak murni ijarah ataupun muzara'ah, jika ia murni ijarah maka seharusnya peralatan dan pembiayaan selama penggarapan ditanggung oleh pemilik tanah dan upah bagi pengelolah bukan dari hasil bumi, dan jika murni muzara'ah maka sistemnya seharusnya adalah bagi hasil, bukan bagian yang sudah ditentukan dari awal tanpa melihat seberapa hasil panen, untung ataukah rugi, namun menurut penuturan pelaku kesepakatan tersebut bisa dikompromikan, dan selama ini kedua belah pihak tidak ada yang dirugikan.

2. Pada jenis kesepakatan kedua, akadnya adalah akad muzara'ah, yaitu bibit ditanggung oleh pemilik tanah sedangkan biaya operasional semuanya ditanggung pengelolah, jika bantuan berupa pupuk dan lainnya dari pihak pemilik tanah tidak disepakati dari awal akad dan hanya sekedar bantuan yang tidak mengikat, maka sah-sah saja, berbeda halnya jika disepakati dari awal akad maka transaksinya dianggap fasid/rusak.

3. Pada kesepakatan ketiga, akadnya adalah muzara'ah, yaitu bibit ditanggung oleh pemilik tanah, dan semua biaya operasional ditanggung oleh pengelolah, akan tetapi pembagian hasil tidak transparan dan 
disepakati dari awal, dan pada praktiknya pengelolah akan menentukan sepihak berapa bagian masing-masing, pada jenis akad ketiga ini jelas ada kecurangan yang dilakukan oleh pihak pengelolah, biasanya hal tersebut terjadi jika pemilik tanah sudah tidak tinggal di daerah setempat bahkan sudah menjadi warga Negara lain semisal Malaysia atau Singapore, tidak ada monitoring, walaupun pada awalnya ada kesepakatan berapa bagian masing-masing namun pada akhirnya pengelolah akan menentukan sendiri berapa hasil yang dia ambil.

\section{Kesimpulan}

Jika dicermati dari ketiga akad di atas maka jenis kesepakatan kedua adalah akad yang sesuai dengan kriteria akad muzara'ah yang ditentukan oleh fukaha, adapun yang pertama ada unsur gharar dan spekulasi di dalamnya, namun begitu kesepakatan tersebut masih bisa dikompromikan yang artinya sejauh ini kedua belah pihak tidak ada yang dirugikan, namun jika kembali kepada akadnya maka termasuk akad yang fasid karena tidak memenuhi syarat-syarat akad muzara'ah.

Jika akadnya fasid/rusak maka ketentuannya adalah :

a. Jika bibit dari pemilik tanah (muzara'ah) maka hasil panen semua adalah haknya, karena bibit tumbuh dan hasil di tanah yang menjadi miliknya, dan bagi pengelolah upah atas usahanya selama ini.

b. Jika bibit dari pengelolah (mukhabarah), maka pengelolah berhak atas hasil panen sekadar jumlah atau nilai dari bibit atau benih yang ditabur, dan upah kerjanya, dan pemilik tanah berhak mendapatkan kadar upah sewa tanahnya.

c. Upah harus diserahkan walaupun gagal panen, maka status muzara'ah dalam kondisi ini menjadi akad ijarah, jika benih dari pemilik tanah maka Ia harus memberi upah kepada pengelolah atas kerjanya walaupun gagal panen, begitu juga pengelolah harus mengeluarkan upah sewa tanah jika 
bibit darinya, berbeda halnya jika akadnya sah, maka untung dan rugi ditanggung bersama, dan tidak ada upah mengupah.

\section{Saran}

Syariat Islam sangat menjaga dan memperhatikan hak dari kedua belah pihak, sehingga diatur sedemikian rupa syarat dan rukun dalam setiap transaksi, hal tersebut bertujuan tercapainya keadilan dan rasa adil, oleh karena itu setiap transaksi harus dilakukan sesuai koridor hukum yang telah ditetapkan, dan bagi setiap pelaku seyogyanya mengetahui dan mempelajari terlebih dahulu tentang hukum transaksi yang akan disepakati, supaya akad atau transaksi yang telah disepakati sah di mata agama dan tidak ada unsur dosa di dalamnya, namun demikian dalam beberapa kondisi terjadi tarik ulur dan kompromi antara kedua belah pihak sehingga mereka membuat kesepakatan sendiri walaupun di kondisi tersebut ada ketidak sesuaian dengan syarat atau kriteria yang telah ditentukan, dalam sebuah hadits disebutkan yang maksudnya adalah muamalah yang terjadi antara orang Islam itu dikembalikan kepada kesepakatan mereka, kerelaan mereka, karena hal ini menyangkut dengan hak adami yang gugur dengan kerelaan atau ridha.

\section{Daftar Pustaka}

Al Qardhawi, Yusuf. Fiqhu az Zakah, Hukum Zakat,Terj. Salman Harun, Jakarta, P.T. Pustaka Litera AntarNusa, 1991.

Az Zuhaili, Wahbah. Al Fiqhu al Islam wa Adillatuhu, Damaskus: Dar al Fikr, 1985. Caudhry, Muhammad Syarif. Sistem Ekonomi Islam Prinsip Dasar. Jakarta: Prenadamedia Group, 2012.

Wizarat al Auqaf wa as Syuun al Islamiyah, Al mausu'ah al fiqhiyah. Kuwait: Dar as Shofwah, 1997 